\title{
Artificial incubation, egg replacement and adoptive parents in bird management: a test with Lesser Elaenia Elaenia chiriquensis
}

\author{
YONARA LOBO and MIGUEL ÂNGELO MARINI
}

\begin{abstract}
Summary
Reducing the time that birds' eggs are exposed during incubation in the wild is a management strategy with the potential to reduce nest predation rates, enhance breeding success and increase the population size of endangered species. We tested whether manipulation of clutches through artificial incubation of Lesser Elaenia Elaenia chiriquensis eggs and subsequent reintroduction of new-born nestlings to their original nest, and the use of adoptive parents, were efficient ways of increasing the population size of this species. We evaluated the financial cost and benefit of three different management strategies of artificial egg incubation with reintroduction of nestlings to the original nest. We searched for nests and manipulated eggs during the breeding seasons of 2009 and 2010 in a savanna reserve in central Brazil. Real eggs were replaced by artificial eggs and artificially incubated. The following breeding parameters were monitored: hatching rate, fledgling productivity, daily survival rate of nestlings and nest success. The effect of nest monitoring frequency (daily or every 3-4 days) on breeding parameters was also tested. Hatching rate was much higher amongst artificially incubated eggs than naturally incubated eggs. Artificially incubated clutches presented higher rates of fledgling production and apparent nest success than non-manipulated clutches. Clutch manipulation did not interfere with nestling daily survival rate. Daily monitoring did not have negative effects. The clutch manipulation methodology we used proved to be viable and is a potential tool for increasing population size.
\end{abstract}

\section{Introduction}

In the tropics, predator abundance and diversity are high and nest predation is also naturally high, affecting up to $80 \%$ of nests (Robinson et al. 2000, Stutchbury and Morton 2001). Like other passerines (Murphy 1983, Martin 1995), high rates of nest predation have been reported for several cerrado (dry savanna woodland) birds, such as Lesser Elaenia Elaenia chiriquensis (67\% of nests lost to predation; Medeiros and Marini 2007), White-banded Tanager Neothraupis fasciata (61\%; Duca and Marini 2011) and Chapada Flycatcher Suiriri islerorum (88\%; França and Marini 2009). In fragmented areas, these already high predation rates seem to be inflated for some species, such as the Chapada Flycatcher, causing its population to decline (França and Marini 2009).

Several management strategies have been applied to reduce nest predation rates and increase reproductive success of wild birds, such as the use of electric fences to protect nests of colonial marine birds (Minsky 1980, Spear et al. 2007) and protective cages around the nests of terrestrial birds (Moseby and Read 2006, Isaksson et al. 2007). Other strategies aimed at increasing reproductive success range from the use of artificial nests, translocation of nestlings to new nest sites (Priddel et al. 2006) to artificial insemination (Blanco et al. 2009). Since conservation and 
management programmes for threatened species are costly and resources are limited, it is important to ensure the cost-effectiveness of such interventions.

Artificial incubation of eggs collected from natural nests of wild birds reduces the period that eggs are exposed in the wild and thus reduces predation risk (Kuehler et al. 1993, 1996, 2000, 2001). So in habitats or regions where nest predation is high, artificial incubation is a potential management tool for increasing reproductive success and population size.

Birds' eggs have all the resources necessary for embryo development (Visschedijk 1991) but also require proper heating, humidity and periodic turning (Klimstra et al. 2009). Artificial incubation creates different conditions from those of natural nests, so a test of artificial egg incubation with cerrado birds is desirable and timely since climate in the region has strong seasonal variation in precipitation (and thus air humidity) (Nimer 1979), birds breed from the end of the dry season through the rainy season (Marini and Durães 2001, Marini et al. 2009b), and average temperature is predicted to increase by $3.5^{\circ} \mathrm{C}$ by 2100 due to climate change (Marini et al. 2009a). Since artificial incubation is still considered an imperfect science and hatching success may be low (Klimstra et al. 2009), incubation variables need to be adjusted for each species. Also, since it may not be possible to first test methodologies with endangered species, the use of a common species is recommended.

In this paper, we report on management strategies employed with the Lesser Elaenia. This is a migratory and frugivorous passerine and an appropriate species for such experimental evaluation since it nests at very high densities in the cerrado of central Brazil (Paiva 2008), it does not desert after clutch manipulations (Sousa 2008) and it is not endangered. Preliminary field tests were carried out in 2008 and experiments conducted in 2009 and 2010, with the goal of evaluating whether various methods of clutch manipulation were an efficient and cost-effective method of improving breeding success. We considered a management tool efficient if it produced a large number of extra fledglings (compared with natural nests) for the least cost (Wilson et al. 2006, Duca et al. 2009). We had one treatment and two controls (Table I). We tested the effects of management strategies on hatching rate, fledgling productivity, daily survival rates (DSR) of eggs, nestlings and nests, and nest success. We also evaluated the financial cost and benefit of three different management strategies of artificial egg incubation with reintroduction of nestlings to the original nest (Table 1 ).

\section{Methods}

\section{Study area}

The study was located at the Estação Ecológica de Águas Emendadas ( $15^{\circ} 29^{\prime}-15^{\circ} 36^{\prime} \mathrm{S}$, $47^{\circ} 31^{\prime}-47^{\circ} 41^{\prime} \mathrm{W}$; mean elevation 1,040 m asl), Distrito Federal, Brazil, a 10,500-ha fragment of cerrado vegetation (Silva Jr. and Felfili 1996). We searched for nests in a 10o ha (1 km x I km) permanent plot located $>_{1} \mathrm{~km}$ from the edge of the reserve, mostly in woodland cerrado ('cerrado sensu stricto') and open cerrado ('cerrado ralo' or 'campo cerrado') (Ribeiro and Walter 1998). The climate of the cerrado region is strongly seasonal, with a cool, dry winter and a warm, rainy summer. Further details are given in Nimer (1979) and Borges and Marini (2010).

\section{Study species}

The study species was the Lesser Elaenia, a passerine with a common clutch size of two eggs (Medeiros and Marini 2007). It is migratory (Marini and Cavalcanti 1990), mostly frugivorous (Marini and Cavalcanti 1998) and very abundant at our study site during its breeding season, from September through late December (Paiva 2008). Nests are open cup structures constructed in bushes or trees located in cerrado sensu stricto (Medeiros and Marini 2007). Nests were located by searching in the vegetation or by following birds with nest material. The incubation period lasts 
Table 1. Schematic representation of the tested management strategy in this study and the three different strategies (one tested and two hypothetical) used to estimate managements costs and benefits.

\begin{tabular}{|c|c|c|c|}
\hline & \multicolumn{3}{|c|}{ Tested management strategy } \\
\hline & Treatment & Control I & Control II \\
\hline \multirow[t]{2}{*}{ Definition } & $\begin{array}{l}\text { - Nests which artificial } \\
\text { incubation of natural eggs }\end{array}$ & $\begin{array}{l}\text { - Nests with eggs } \\
\text { incubated naturally } \\
\text { by their parents }\end{array}$ & $\begin{array}{l}\text { - Nests with eggs incubated } \\
\text { naturally by their parents }\end{array}$ \\
\hline & $\begin{array}{l}\text { - Replacement of natural } \\
\text { eggs by plaster eggs } \\
\text { - With replacement of predated } \\
\text { plaster eggs by new plaster } \\
\text { eggs in natural nests during } \\
\text { the incubation period } \\
\text { - Use of adoptive parents } \\
\text { when natural nests were } \\
\text { destroyed during incubation } \\
\text { period }\end{array}$ & & \\
\hline \multirow[t]{3}{*}{ Monitoring } & Daily & Daily & Every 3-4 days \\
\hline & \multicolumn{3}{|c|}{ Three different strategies used to estimate managements cost and benefit } \\
\hline & $\begin{array}{c}\text { Hypothetical management } \\
\text { scenarios } \\
\text { I }\end{array}$ & $\begin{array}{l}\text { Hypothetical management } \\
\text { scenarios } \\
\text { II }\end{array}$ & $\begin{array}{c}\text { Tested management } \\
\text { strategy - Treatment } \\
\text { III }\end{array}$ \\
\hline Definition & $\begin{array}{l}\text { - Replacement of natural eggs } \\
\text { by plaster eggs } \\
\text { - Without replacement of } \\
\text { depredated plaster eggs by } \\
\text { new plaster eggs in natural } \\
\text { nests during the incubation } \\
\text { period } \\
\text { - Artificial incubation of } \\
\text { natural eggs }\end{array}$ & $\begin{array}{l}\text { - Replacement of natural } \\
\text { eggs by plaster eggs } \\
\text { - With replacement of } \\
\text { depredated plaster eggs } \\
\text { by new plaster eggs in } \\
\text { natural nests during } \\
\text { the incubation period } \\
\text { - Artificial incubation } \\
\text { of natural eggs } \\
\text { - Without adoptive parents } \\
\text { when natural nests were } \\
\text { destroyed during } \\
\text { incubation period }\end{array}$ & $\begin{array}{l}\text { - Replacement of natural } \\
\text { eggs by plaster eggs } \\
\text { - With replacement of } \\
\text { predated plaster eggs } \\
\text { by new plaster eggs in } \\
\text { natural nests during the } \\
\text { incubation period } \\
\text { - Artificial incubation of } \\
\text { natural eggs } \\
\text { - Use of adoptive parents } \\
\text { when natural nests were } \\
\text { destroyed during } \\
\text { incubation period }\end{array}$ \\
\hline Monitoring & Every $3-4$ days & Daily & Daily \\
\hline
\end{tabular}

on average 14 days and the nestling period averages 15 days. Further nesting details are provided in Medeiros and Marini (2007).

\section{Experimental design}

We searched for nests during the breeding season, from September to December, 2009-2010. Empty nests and one-egg nests found were monitored every two days or every day, respectively, to record the exact day of clutch completion. We manipulated clutches with two eggs that were completed within $24 \mathrm{~h}$ of each other (hereafter "manipulated"). We transferred natural eggs to an incubator and replaced them with artificial plaster eggs of similar size and colour. Egg replacement had the objective of avoiding nest abandonment by parents and allowing the reintroduction of new-born nestlings to their original nest. We monitored nests daily, in order to replace predated eggs by new ones as soon as they were predated. We used the same daily monitoring scheme 
with another group of nests (hereafter "control I"), but without any clutch manipulation. Since the monitoring frequency of nests may increase nest predation and abandonment (Major 1989, Bolduc and Guillemette 2003), we tested the effect of nest monitoring frequency comparing control I with another group of non-manipulated clutches (hereafter "control II") monitored every 3-4 days.

We replaced natural eggs by artificial eggs to try to avoid nest abandonment by parents while natural eggs were in the incubator. We replaced both eggs of each nest with two plaster eggs immediately after the second egg was laid. Since parents maintain nest sanitation by removing egg shells, faecal sacs and alien material (Blair 1941, Nethersole-Thompson and NethersoleThompson 1941), we placed a small green leaf inside the nest to evaluate egg acceptance. If the leaf was removed from the nest up to 24 hours after its placement and parents were seen near the nest, we considered eggs accepted and the nest active. After being replaced by plaster eggs, we protected natural eggs with cotton wool and stored them inside individual acrylic vials with holes in the lid to allow gas exchange. We transported eggs to a portable incubator located in a dark incubation room up to 50 min away from the field site.

Eggs were set in an incubator (Premium Ecológica - IP 35 PDA) and artificially incubated and hatched ( $\sim_{14}$ days) at $37.5^{\circ} \mathrm{C}$ and $55 \%$ air humidity. Eggs were set horizontally, and mechanically turned through $180^{\circ}$ on their longitudinal axis every two hours. We candled eggs every three days to monitor embryo development. On the expected day before hatching, we removed eggs from incubator rollers and placed them in a cloth "nest" inside the incubator to avoid nestling death after hatching by getting trapped in the roller.

After hatching, we fed new-borns with a commercial nestling food on average every $40 \mathrm{~min}$ until reintroduced to the nest. We usually removed nestlings from the incubator every day at o8hoo. For nestlings born after o8hoo, removal from the incubator occurred the next day at o8hoo. Thus, most nestlings stayed in captivity for less than 24 hours after hatching. We transported nestlings and fragments of their egg shells in an insulated box at $37^{\circ} \mathrm{C}$. To simulate hatching, we replaced plaster eggs with the new-born nestlings and egg shells. We considered nestlings accepted by parents if they were still in the nest and egg shells were removed after $30 \mathrm{~min}$.

We introduced nestlings into nests of adoptive parents when their original nests had been lost (predated or abandoned) during the incubation period. This allowed us to return nestlings to nature instead of sacrificing them. We selected adoptive parents from a pool of dozens of other natural nests found and monitored in the study area. To avoid rejection by adoptive parents or siblings ( $\mathrm{O}^{\prime}$ Connor 1978) we used only nests with one or two nestlings at the same developmental stage ( \pm 1 day) of the orphan nestlings. Each nest with adopted parents received one or two nestlings, to a maximum of three nestlings per nest. We marked introduced, or reintroduced, nestlings on the tarsus with non-toxic paint.

We monitored nests of both artificially incubated eggs (manipulated) and naturally incubated eggs (control I) daily, and naturally incubated eggs (control II) every 3-4 days, until eggs hatched. Since clutch manipulations were restricted to the egg period, once nestlings had been reintroduced to their nests, we monitored all nests (manipulated and controls I and II) every 3-4 days. We classified nest fates as: 1) successful, when incubation lasted at least 14 days or when nestlings reached at least 13 days of age (minimum incubation period or minimum age for a egg to hatch or a nestling to fledge, respectively; Medeiros and Marini 2007); 2) depredated, when nest contents were found damaged or disappeared before the minimum expected age of eggs/nestlings to fledge successfully; 3 ) abandoned, when adults were not observed attending the nest and eggs were cold.

\section{Management considerations}

To evaluate the viability of the management strategy, we calculated acceptance rate of plaster eggs by parents, as well as acceptance of reintroduced nestlings. We calculated the percentage of nests with plaster eggs that were still active after predation events and replacement of predated eggs 
with new plaster eggs. We also calculated the percentage of naturally and artificially incubated eggs that did not hatch. Lastly, we quantified the number of eggs and nestlings lost due to handling.

To evaluate overall management cost we summed the cost of field expenses with labour $(\sim$ US\$ 58.48/day), fuel for cars ( 100 km/day, US\$ $0.58 / \mathrm{km})$, as well as products used to make artificial eggs, to transport eggs and nestlings, food for nestlings, and the incubator. We estimated the cost for the artificial incubation methodology used in this study, as well as for egg replacement, with or without adoptive parents. We also estimated the cost for the hypothetical methodology of artificial incubation and egg replacement, but without replacement of depredated artificial eggs, i.e. after the predation of a nest with artificial eggs, the nest would be presumed to become inactive.

To estimate costs with fuel and labour, we first determined field effort (number of days) for each methodology using the following assumptions: (I) two people search for nests and one undertakes all the other activities; (2) each person is able to find five nests per day, totalling io nests found per day; (3) nests are found when nest building was half completed, and the interval to the laying of the second egg is eight days; (4) the nest searching period consists of consecutive days, including weekends and holidays; (5) the incubation period lasted 14 days and nestling period 15 days; (6) trips to the study site were daily after the first nestling was returned to the nest, since after the first egg hatched, hatching became daily and at least one nestling was returned to the nest; (7) after a nestling was returned to the nest, monitoring occurred every 3-4 days. We estimated costs for each methodology considering a manipulation of 30 nests each. To estimate the number of days required to search for nests, we first estimated the number of nests necessary to have 30 manipulated nests + nests to be used as adoptive parents (when necessary). We considered a nest predation rate of $9.6 \%$ until laying of the second egg (for manipulated nests) and $57 \%$ for the incubation period (for nests with adoptive parents), based on field data obtained during nest monitoring in this study. Then, we divided the number of required nests by 10, which is the maximum number of nests found in one nest-searching day. Finally, we obtained the number of days required to search for enough nests to manipulate and use as adoptive parents.

\section{Statistical analyses}

We compared hatching rate (number of eggs hatched by number of eggs incubated per nest) (Mayfield 1975) among clutch-manipulated and control I nests, and control I and control II nests, using a Mann-Whitney U-test. We compared fledgling productivity (number of fledglings per nest; Ricklefs and Bloom 1977) among clutch-manipulated and control I nests, and control I and control II nests, using a Chi-square test. We calculated the apparent success (percentage of successful nests) and did not use Mayfield (Mayfield 1975) or logistic-exposure (White and Burnham 1999) methods for clutch manipulation because nests with eggs artificially incubated were either successful or not. We compared the apparent success among clutch-manipulated and control I nests using a Chi-square test. We set $\alpha$-level at $5 \%$ for all tests, and for all analyses we present means followed by standard error (SE).

We used program MARK (Version 4.3) to estimate daily survival rate (DSR) of eggs, nestlings and the full nest period. To test whether there was any negative clutch manipulation interference on nestling survival after their reintroduction to the nest, we estimated daily survival rates during nestling periods of clutch-manipulated and control I nests. To test the effect of monitoring frequency on breeding parameters, we estimated daily survival rates of eggs and nestling periods separately and also for the full nesting period (egg and nestling periods) of control I and control II clutches. Although the breeding success of birds can vary throughout the breeding season (Nilsson 1989, Hochachka 1990), we did not consider temporal variations in DSR because our study period was short. Thus, we used the null model similar to Mayfield's (1961, 1975) estimate, that considers DSR as constant over the breeding season (Dinsmore et al. 2002). We calculated 
Mayfield success (1961, 1975) for control I and II, raising DSRs of the null model to the number of days needed to complete the nest cycle (one day of laying +14 days of incubation +13 days of minimum duration of nestlings in the nest).

Clutch-manipulated nests were analysed in two ways: a) with use of adoptive parents when natural nests were destroyed during incubation period; and b) the hypothetical case without use of adoptive parents, when nestlings whose original nests have been destroyed and would not be returned to nature (sacrificing).

\section{Results}

We monitored 50 manipulated nests (20 in 2009 and 30 in 2010), 40 control I ( 18 in 2009 and 31 in 2010) and 118 control II ( 55 in 2009 and 63 in 2010) with two eggs each in the two years.

\section{Management considerations}

Considering all nests from both years, there was a 100\% acceptance of artificial eggs by parents. Considering all 77 nestlings reintroduced to nests, 96\% $(n=74)(91 \%$ in 2009 and $100 \%$ in 2010) were accepted by parents. Two manipulated nests were abandoned by parents a few days after they had accepted and incubated artificial eggs. Among the 50 manipulated nests with artificial eggs, $64 \%(65 \%$ in 2009 and $63 \%$ in 2010$)$ were predated during the egg period. However, because of the replacement of artificial eggs lost by predation, $38 \%$ (46\% in 2009 and $32 \%$ in 2010) of these predated nests were not abandoned by parents, allowing the reintroduction of their own artificially incubated nestlings.

The percentage of eggs that did not hatch was higher for artificially incubated ( $18 \%$ in 2009 and $25 \%$ in 2010) than for natural eggs (0.5\% in 2009 and $3.8 \%$ in 2010) after three days since the first egg hatched. For natural nests, we considered only the nests in which none of the eggs was predated during the incubation phase, and that after the first egg hatched, the second egg remained unhatched in the nest for at least three days. It was not possible to monitor egg fertility at the start of artificial incubation since eggs were removed from nests immediately after laying.

During all experiments, 22 eggs and one nestling were lost. Of these eggs, 19 (five in 2009 and 14 in 2010) did not hatch and three (two in 2009 and one in 2010) were accidentally broken. The nestling died in 2010 for an unknown reason after it was removed from the incubator.

The cost of manipulating 30 nests, for the methodology with egg replacement after predation events of manipulated clutches, was US\$ 6,105.18 (in December 2010) with the use of adoptive parents, and US\$ 3,415.12 without the use of adoptive parents (Table 2). The cost of the same methodology for 30 nests without egg replacement is only US\$2,625.64.

The management cost per fledgling produced for each methodology was: US\$218.04 for the methodology with egg replacement and adoptive parents (28 fledglings produced); US\$ 170.76 for the methodology with egg replacement but without adoptive parents (2o fledglings produced); and US\$ 201.97 for the methodology without egg replacement (an estimate of 13 fledglings produced).

\section{Effect of artificial incubation}

The average hatching rate increased with management. There was a significant $(U=1,827.0$; $\mathrm{df}=49,50 ; P<$ o.001) increase in average hatching rate of eggs incubated artificially $(78 \%)$ when compared with eggs from control I (36\%) (Table 2).

The DSR of nestlings was apparently not affected by management strategy over the two years. DSRs were slightly lower in 2009 and slightly higher in 2010 for eggs incubated artificially with and without adoptive parents than for eggs from control I (Table 3). DSR of nestlings with their natural or with adoptive parents was similar in both years (Table 3 ). 
Table 2. Total management costs of the three methodologies: (1) artificial incubation of eggs without egg replacement by artificial eggs; (2) artificial incubation of eggs with replacement of field predated plaster eggs in natural nests during the incubation period, c) artificial incubation, egg replacement and use of adoptive parents when natural nests were destroyed during incubation period.

\begin{tabular}{|c|c|c|c|}
\hline \multirow[t]{2}{*}{ Expenditures } & \multirow{2}{*}{$\begin{array}{l}\text { Without replacement } \\
\text { of the artificial eggs } \\
\text { Hypothetical } \\
\text { management strategy } \\
\text { monitoring 3-4 days }\end{array}$} & \multicolumn{2}{|c|}{ With replacement of the artificial eggs } \\
\hline & & $\begin{array}{l}\text { Hypothetical } \\
\text { management } \\
\text { strategy (without } \\
\text { adoptive parents) } \\
\text { daily monitoring }\end{array}$ & $\begin{array}{l}\text { Tested management } \\
\text { strategy (with adoptive } \\
\text { parents) daily } \\
\text { monitoring }\end{array}$ \\
\hline Fuel & US\$ 584.79 & US\$ $847 \cdot 95$ & US\$ $1,432.74$ \\
\hline Human labour & US\$ $1,403.50$ & US\$ $1,929.82$ & US\$ $4,035.08$ \\
\hline $\begin{array}{l}\text { Products used in the } \\
\text { manufacture of eggs, } \\
\text { transport of eggs/nestlings } \\
\text { and feeding of nestlings }\end{array}$ & US\$ 52.54 & US\$ 52.54 & US\$ 52.54 \\
\hline Incubator & US\$ 584.79 & US\$ 584.79 & US\$ 584.79 \\
\hline TOTAL COST & US\$2,625.64 & US\$ $3,415.12$ & US\$ 6,105.18 \\
\hline
\end{tabular}

Fledgling production was low for nests of control I (0.20 fledglings/nest; 0.28 in 2009 and 0.19 in 2010), intermediate for incubated eggs without adoptive parents (0.40; 0.60 in 2009 and 0.27 in 2010) and high for nestlings with adoptive parents (0.60; 0.79 in 2009 and 0.47 in 2010). However, fledgling production from incubated eggs was not significantly higher $\left(\chi_{2}^{2}=1.043\right.$; $P=0.594$ ) than from control I nests, using pooled data from both years (Table 3 ). However,

Table 3. Breeding parameters of Lesser Elaenia Elaenia chiriquensis of control I $(n=49)$, control II and manipulated $(n=50)$ nests for $2009+2010$ (hatching rate, fledgling production, and nest apparent success) and each year separately (daily survival rate and Mayfield nest success).

\begin{tabular}{|c|c|c|c|c|}
\hline \multirow[t]{3}{*}{ Breeding parameters } & \multicolumn{4}{|c|}{ Clutch manipulation treatments } \\
\hline & \multirow[t]{2}{*}{ Control I } & \multirow[t]{2}{*}{ Control II } & \multicolumn{2}{|l|}{ Manipulated } \\
\hline & & & $\begin{array}{l}\text { without } \\
\text { adoptive } \\
\text { parents }\end{array}$ & $\begin{array}{l}\text { with } \\
\text { adoptive } \\
\text { parents }\end{array}$ \\
\hline Hatching rate $\pm \mathrm{EP}(\%)$ & $36 \pm 7^{*}$ & $31 \pm 4$ & $78 \pm 5^{*}$ & \\
\hline \multicolumn{5}{|l|}{ Daily survival rates \pm EP (2009) } \\
\hline Egg & $0.923 \pm 0.023$ & $0.929 \pm 0.012$ & - & - \\
\hline Nestling & $0.955 \pm 0.025$ & $0.918 \pm 0.021$ & $0.941 \pm 0.021$ & $0.934 \pm 0.019$ \\
\hline Nest & $0.936 \pm 0.017$ & $0.931 \pm 0.009$ & - & - \\
\hline \multicolumn{5}{|l|}{ Daily survival rates $\pm \mathrm{EP}$ (2010) } \\
\hline Egg & $0.927 \pm 0.016$ & $0.916 \pm 0.012$ & - & - \\
\hline Nestling & $0.895 \pm 0.030$ & $0.919 \pm 0.020$ & $0.918 \pm 0.025$ & $0.934 \pm 0.015$ \\
\hline Nest & $0.927 \pm 0.016$ & $0.919 \pm 0.010$ & - & - \\
\hline Fledgling production rate & $0.2^{* *}$ & 0.2 & 0.4 & $0.6^{* *}$ \\
\hline Nest apparent success (\%) & $14.2^{* * *}$ & - & 26.0 & $42.0 * * *$ \\
\hline Mayfield success (\%) (2009) & 16.0 & 12.0 & - & - \\
\hline Mayfield success (\%) (2010) & 14.0 & 9.0 & - & - \\
\hline
\end{tabular}


when nestlings from adoptive parents are considered, nests with artificially incubated eggs had significantly higher $\left(\chi_{2}^{2}=8.57 ; P=0.014\right)$ fledgling production than control I (Table 3 ).

In a similar way to the fledgling production rate, the apparent success of nests was low for control I (14\%; $22 \%$ in 2009 and $10 \%$ in 2010), intermediate for incubated eggs without adoptive parents $(26 \% ; 40 \%$ in 2009 and $17 \%$ in 2010$)$ and high for nestlings with adoptive parents (42\%; 50\% in 2009 and $37 \%$ in 2010) (Table 3). Nests from control I, however, differed significantly $\left(\chi^{2}{ }_{1}=8.055 ; P=0.002\right)$ only from manipulated nests with adoptive parents, and were similar to manipulated nests without adoptive parents $\left(\chi_{1}^{2}=1.443 ; P=0.230\right)$.

\section{Effect of nest monitoring frequency}

Nest monitoring frequency did not affect hatching rate. Even though nests from control I were monitored more frequently than nests from control II, average hatching rate was similar $(U=2,735.0 ; \mathrm{df}=49,118 ; P=0.522)$ between control I (36\%) and control II (31\%) (Table 3$)$.

Nest monitoring frequency apparently also had no effect on average DSR during egg or nestling periods, since differences were small between control I and II and similar, but in opposite directions, between 2009 and 2010 (Table 3). DSRs over all the nest period, however, were also similar, but slightly higher in both years in control I than in control II (Table 3).

Fledgling production was similar between nests with different nest monitoring frequencies. Nests from control I (average of 0.22 fledglings/nest; 0.28 in 2009 and 0.19 in 2010) had similar $\left(\chi_{2}^{2}=2.322 ; P=0.313\right.$ ) fledgling production to nests of control II (average of 0.21 fledglings/ nest; 0.24 in 2009 and 0.19 in 2010) (Table 3). Fledgling production was lower in 2010 than in 2009 for both treatments.

Contrary to what was predicted, nesting success increased slightly with an increase in nest monitoring frequency. Nests from control I had higher nesting success (16\% in 2009 and $14 \%$ in 2010) than nests from control II (12\% in 2009 and $9 \%$ in 2010) (Table 3). Nesting success was lower in 2010 than in 2009 for both treatments.

\section{Discussion}

\section{Clutch manipulation efficiency}

Our results clearly showed that clutch manipulation is an efficient method of increasing the hatching rate of Lesser Elaenia. Hatching rates are usually low in wild nests of tropical birds (Skutch 1966). A pattern of high hatching rates of artificially incubated eggs has also been obtained in other species such as Oma'o Myadestes obscurus (93\%) and Palila Loxioides bailleui (96\%) (Kuehler et al. 1993, 1996, 2000, 2001).

Although expected and desired, a hatching rate of $100 \%$ will seldom be obtained by artificial incubation due to several factors. Eggs might be naturally infertile, and embryos might not develop due to pre-incubation problems (parental genetics, nutrition, maternal age, and environmental conditions; French and Tullett 1991, Christensen 2001). Failure might also be related to inappropriate incubation conditions (temperature, humidity, oxygen and turning of the eggs; Tullet 1990, Meijerhof 1992), and accidental loss due to egg/nestling manipulation (Graber 1955, Snelling 1972, Klimstra et al. 2009).

Estimates of nest survival are an efficient way to evaluate strategies for conservation and management of bird populations (Jehle et al. 2004). DSRs of nestlings of control or manipulated nests were relatively similar and suffered small variations between years and treatments, probably due to uncontrolled factors such as predation risk and nest attendance by parents (Skutch 1949), or characteristics of the nesting site (Fontaine et al. 2007). Thus, we did not find any negative effect due to the presence of observers during nest manipulation. Although DSRs did not vary much among treatments, our results clearly showed that clutch manipulation increased fledgling production. However, fledgling production varied considerably between 
2009 and 2010, but was always lower for control I and higher for manipulated nests with adoptive parents (Table 3). These variations between years due to natural environmental factors may cause unpredictability in results or expectations of conservation programmes. The fact that breeding parameters were better with adoptive parents highlights the importance of having a large number of non-manipulated nests available to attain more positive results with this management strategy.

Similar to hatching rate and fledgling production, apparent nest success was lowest for control I nests, and highest for manipulated nests with adoptive parents. Consistent with other breeding parameters, variations between 2009 and 2010 were as high as variations among treatments and limit comparisons with other species. Despite this high variation between years, the success of manipulated nests with adoptive parents was usually much higher than the success of other passerines nesting in the same study area: Suiriri Flycatcher Suiriri suiriri, 19\% and Chapada Flycatcher, 14\% (Lopes and Marini 2005); Plain-crested Elaenia Elaenia cristata, 27\% (Marini et al. 2009b); and White-banded Tanager, 29\% (Duca and Marini 2011). This comparison with other species shows the potential use of clutch manipulation of these species with low breeding success or in species with declining populations, such as Chapada Flycatcher (França and Marini 2010).

\section{Management considerations}

The major advance of our study in relation to others is the demonstration that it is not always necessary to raise nestlings or fledglings in captivity, and thus incur additional costs with fledgling/young reintroduction programmes. By maintaining the female incubating artificial eggs, we were able to return nestlings to a nest soon after hatching, decreasing costs of the management programme and maintaining all the behavioural benefits of parental care. Overall, our results clearly showed that any amount of clutch manipulation had a positive effect on several breeding parameters of Lesser Elaenia. Better results were usually obtained when adoptive parents were used instead of not returning (sacrificing) nestlings without nests. The use of adoptive parents, however, depends on finding a large number of extra non-manipulated nests. This was possible for the Lesser Elaenia since this species is very abundant at our study site, and a large ( 8-12 people) field team found 100-300 active nests of this species each year from 2005 to 2010 (Marini unpubl. data). The use of this methodology is limited to species with a population size large enough to have nests that can be used by adoptive parents. Thus, the use of adoptive parents, even though desirable, might not be feasible in species with low population densities or whose nests are difficult to find.

Three parents rejected nestlings reintroduced into their nests. The rejection of these nestlings was probably related to low body condition, a quality apparently assessed by parents. One of these nestlings was not able to completely leave the eggshell, and the others took too long to hatch and appeared to be weak. Also, selective rejection seems the case, since the same parents that rejected one of these nestlings accepted another nestling later.

The use of clutch manipulation may not be a panacea for all species, since some are intolerant of human presence at their nesting site (Gotmark 1992, Carney and Sydeman 1999). Lesser Elaenia accepted artificial eggs for incubation, accepted most reintroduced and introduced nestlings and did not abandon nests because of daily nest monitoring. Some authors have reported higher predation rates on nests frequently monitored (Major 1989, Martin 1993). Our tests indicate that nest monitoring frequency had no negative effect on Lesser Elaenia breeding parameters, as also reported by Cotter and Gratto (1995), Verboven et al. Dechesne (2001), and Bolduc and Guillemete (2003). Contrary to expected, nests monitored daily (control I) tended to have a higher hatching rate, higher DSR, and higher Mayfield nesting success than nests monitored every 3-4 days. The higher DSR and nestling success might be explained by avoidance of humans by predators.

Several other methodologies were not used in this study, but could have improved management success. For example, playback of vocalisations of parents and siblings during the last days of artificial incubation can stimulate nestlings to break and leave the egg (Kuehler et al. 200o). Eggs 
accidentally broken or cracked during manipulation can be repaired with white glue when egg contents are not lost (Mace 1987). Lastly, one day before hatching, eggs could have been transferred to a hatcher, a place with better temperature and humidity for a newly-hatched chick than an incubator (Burnham 1983, Klimstra et al. 2009).

The long dry season of 2010 may also explain some clutch manipulation differences between years. For example, a higher percentage of eggs did not hatch in 2010 than in 2009, most of them transferred to the incubator before the start of the rains. Also, a higher percentage of unhatched eggs were observed in 2010 than in 2009. Embryo death in mid- or late development may be related to low female investment in egg production (Martin 1987, French and Tullett 1991).

\section{Management costs}

The methodology of replacing natural eggs with artificial eggs and the use of adoptive parents was financially the most costly. Thus, this methodology is not the most appropriate for management programmes with limited resources. For these programmes, egg replacement without adoptive parents produces the least costly fledglings.

The costs and benefits of producing an extra chick by this methodology might decrease with larger field teams and artificial incubation facilities closer to or at the field sites. Thus, hiring more people to search for nests might increase the efficiency of the methodology and decrease costs, since several other costs are fixed and not related to the number of people. Fuel costs might be decreased if the incubation facilities are at or closer to the field site.

Our methodology integrating in situ and ex situ management might have lower costs than other management methodologies since the immediate return of newly-hatched nestlings to the nest does not require the high additional costs of captive rearing and reintroduction programmes. Two decades ago, it was estimated that the cost of captive breeding programmes of endangered species may already involve around half a million dollars per year per species (Derrickson and Snyder 1992). Similar studies using artificial incubation of wild bird eggs have achieved positive results, but at a higher cost compared with this study, as they require the reintroduction of young full-grown birds to their original habitats (Kuehler et al. 1996, 2000, 2001). Besides the expense, the re-introduction of birds might not be effective and even cause impacts if there is no appropriate planning and nest monitoring after release (review in Marini and Marinho-Filho 2005). Even well-planned reintroduction programmes might not achieve success, as happened with Spix's Macaw Cyanopsitta spixii (Bampi and Da-Ré 1994).

\section{Acknowledgements}

This study was partly funded by a research grant from Conselho Nacional de Desenvolvimento Científico e Tecnológico - CNPq - Brazil and grants from Fundação de Apoio à Pesquisa do Distrito Federal (FAP-DF). We thank CNPq for a researcher fellowship to MÂM and for scholarship to YL. We are thankful to ESECAE's administration for permission to work in the area, and to IBAMA for authorisations (licences no. 15968-2 and no. 25699-1 - SISBIO). We thank all students from Laboratório de Ecologia e Conservação de Aves at Universidade de Brasília for field support.

\section{References}

Bampi, M. I. and Da-Ré, M. (1994) Recovery program for the Spix's Macaw (Cyanopsitta spixii): conservation in the wild and reintroduction program. http://www.bluemacaws. org acessado em 05/01/11.
Blair, R. H. (1941) Nest-sanitation. With additions from published sources by B. W. Tucker Brit. Birds 34: 206-215, 226-235, 250-255.

Blanco, J. M., Wildt, D. E., Hofle, U., Voelker, W. and Donoghue, A. M. (2009) 
Implementing artificial insemination as an effective tool for ex situ conservation of endangered avian species. Theriogenology 71: 200-213.

Bolduc, F. and Guillemette, M. (2003) Human disturbance and nesting success of Common Eiders: interaction between visitors and gulls. Biol. Conserv. 110: 77-83.

Borges, F. J. A. and Marini, M. Â. (2010) Birds nesting survival in disturbed and protected Neotropical savannas. Biodivers. Conserv. 19: $223-236$.

Burnham, W. (1983) Artificial incubation of falcon eggs. J. Wildl. Manage. 47: 158-168.

Carney, K. M. and Sydeman, W. J. (1999) A review of human disturbance effects on nesting colonial waterbirds. Waterbirds 22: 68-79.

Christensen, V. L. (2001) Factors associated with early embryo mortality. World Poult. Sci. J. 57: 359-372.

Cotter, R. C. and Gratto, C. J. (1995) Effects of nest and brood visits and radio transmitters on Rock Ptarmigan. J. Wildl. Manage. 59: 93-98.

Derrickson, S. R. and Snyder, N. F. R. (1992) Potentials and limits of captive breeding in parrot conservation. Pp. $133-163$ in S. R. Beissinger and N. F. R. Snyder, eds. New World parrots in crisis: solutions from conservation biology. Washington, DC: Smithsonian Institution Press.

Dinsmore, S. J., White, G. C. and Knopf, F. L. (2002) Advanced techniques for modeling avian nest survival. Ecology 83:34763488 .

Duca, C. and Marini, M. Â. (2011) Variation in breeding of the Shrike-like Tanager in central Brazil. Wilson J. Ornithol. 123: 259-265.

Duca, C., Yokomizo, H., Marini, M. Â. and Possingham, P. H. (2009) Cost-efficient conservation for the White-banded tanager (Neothraupis fasciata) in the Cerrado, central Brazil. Biol. Conserv. 142: 563-574.

Fontaine, J. J., Martel, M., Markland, H. M., Niklison, A. M., Decker, K. L. and Martin, T. E. (2007) Testing ecological and behavioral correlates of nest predation. Oikos 116: 1887-1894.

França, L. F. and Marini, M. Â. (2009) Low and variable reproductive success of a neotropical tyrant-flycatcher, Chapada Flycatcher (Suiriri islerorum). Еmu 109: 265-269.

França, L. F. and Marini, M. Â. (2010) Negative trend in population size in a Neotropical flycatcher (Suiriri islerorum) despite high apparent annual survival. J. Field Ornithol. 81: 227-236.

French, N. A. and Tullett, S. G. (1991) Variation in egg of poultry species. Pp. 59-77 in S. G. Tullett, ed. Avian incubation. London: Butterworth Heinemann Ltd.

Gotmark, F. (1992) The effects of investigator disturbance on nesting bird. Pp. 63-104 in D. M. Power, ed. Current Ornithology 9. New York: Plenum Press.

Graber, R. R. (1955) Artificial incubation of some non-galliform eggs. Wilson Bull. 67: 100-109.

Hochachka, W. (1990) Seasonal decline in reproductive performance of Song Sparrows. Ecology 71: 1279-1288.

Isaksson, D., Wallander, J. and Larsson, M. (2007) Managing predation on groundnesting birds: the effectiveness of nest exclosures. Biol. Conserv. 136: 136-142.

Jehle, G., Adams, A. A. Y., Savidge, J. A. and Skagen, S. K. (2004) Nest survival estimation: a review of alternatives to the Mayfield estimator. Condor 106: 472-484.

Klimstra, J. D., Stebbins, K. R., Heinza, G. H., Hoffmana, D. J. and Kondradc, S. R. (2009) Factors related to the artificial incubation of wild bird eggs. Avian Biol. Res. 2: 121-131.

Kuehler, C. M., Lieberman, A., Mcllraith, B., Everett, W., Scott, T. A., Morrison, M. L. and Winchell, C. (1993) Artificial incubation and hand-rearing of Loggerhead Shrikes. Wildl. Soc. Bull. 21: 165-71.

Kuehler, C., Kuhn, M., Kuhn, J. E., Lieberman, A., Harvey, N. and Rideout, B. (1996) Artificial incubation, hand-rearing, behavior, and release of Common 'Amakihi (Hemignathus virens virens): Surrogate research for restoration of endangered Hawaiian forest birds. Zoo Biol. 15: 541-553.

Kuehler, C., Lieberman, A., Oesterie, P., Powers, T., Kuhn, M., Kuhn, J., Neslon, J., Snetsinger, T., Herrmann, C., Harrity, P., Tweed, E., Fancy, S., Woodworth, B. and Telfer, T. (2000) Development of restoration techniques for Hawaiian thrushes: collection of wild eggs, artificial incubation, 
hand-rearing, captive breeding, and reintroduction to the wild. Zoo Biol. 19: 263277.

Kuehler, C., Lieberman, A., Harrity, P., Kuhn, M., Kuhn, J., McIlraith, B. and Turner, J. (2001) Restoration techniques for Hawaiian forest birds: collection of eggs, artificial incubation and hand-rearing of chicks, and release to the wild. Stud. Avian Biol. 22: 354-358.

Lopes, L. E. and Marini, M. Â. (2005) Low reproductive success of Campo Suiriri (Suiriri affinis) and Chapada Flycatcher (S. islerorum) in the central Brazilian Cerrado. Bird Conserv. Internatn. 15: 337-346.

Mace, M. E. (1987) Repairing egg fractures of the Abyssinian ground hornbill (Bucorvus abyssinicus). Avicult. Mag. 93: 21-23.

Major, R. E. (1989) The effect of human observers on the intensity of nest predation. Ibis 132: 608-612.

Marini, M. Â. and Cavalcanti, R. B. (1990) Migrações de Elaenia albiceps chilensis e Elaenia chiriquensis albivertex (Aves, Tyrannidae). Bol. Mus. Para. Emílio Goeldi 6: 59-66.

Marini, M. Â. and Cavalcanti, R. B. (1998) Frugivory by Elaenia Flycatchers. Hornero 15: 47-50.

Marini, M. Â. and Durães, R. D. (2001) Annual pattern of molt and reproductive activity of passerines in south-central Brazil. Condor 115: 767-775.

Marini, M. Â. and Marinho-Filho, J. S. (2005) Translocação de aves e mamíferos: teoria e prática no Brasil. Pp. 505-536 in F. D. Rocha, H. G. Bergallo, M. V. Sluys and M. A. S. Alves, ed. Biologia da conservação: Essências. São Paulo: Ed. Rima.

Marini, M. Â., Barbet-Massin, M., Lopes, L. E. and Jiguet, F. (2009a) Predicted climatedriven bird distribution changes and forecasted conservation conflicts in a neotropical savanna. Conserv. Biol. 23: 1558-1567.

Marini, M. Â., Matos, N. O., Borges, F. J. L. and Silveira, M. B. (2009b) Biologia reprodutiva de Elaenia cristata (Aves: Tyrannidae) em cerrado do Brasil Central. Neotrop. Biol. Conserv. 4: 3-12

Martin, T. E. (1987) Food as a limit on breeding birds: a life-history perspective. Ann. Rev. Ecol. Syst. 18: 453-487.
Martin, T. E. (1993) Nest predation among vegetation layers and habitat types: revising the dogmas. Am. Nat. 141: 897-913.

Martin, T. E. (1995) Avian life history evolution in relation to nest sites, nest predation, and food. Ecol. Monogr. 65: 101-127.

Mayfield, H. (1961) Nesting success calculated from exposure. Wilson Bull. 73: 255-261.

Mayfield, H. (1975) Suggestions for calculating nest success. Wilson Bull. 87: 456-466.

Medeiros, R. C. S. and Marini, M. Â. (2007) Biologia reprodutiva de Elaenia chiriquensis (Lawrence) (Aves, Tyrannidae) em cerrado do Brasil Central. Rev. Bras. Zool. 24: 12-20.

Meijerhof, R. (1992) Pre-incubation holding of hatching eggs. World Poult Sci. J. 48: 57-68.

Minsky, D. (1980) Preventing fox predation at a Least Tern colony with an electric fence. J. Field Ornithol. 51: 180-181.

Moseby, K. E. and Read, J. L. (2006) The efficacy of feral cat, fox and rabbit exclusion fence designs for threatened species protection. Biol. Conserv. 127: 429-437.

Murphy, M. T. (1983) Nest success and nesting habitats of Eastern Kingbirds and other flycatchers. Condor 85: 208-219.

Nethersole-Thompson, C. and NethersoleThompson, D. (1941) Egg shell disposal by birds. Brit. Birds 35: 162-169, 190-208, 214-223, 241-250.

Nilsson, J. A. (1989) Causes and consequences of natal dispersal in the Marsh Tit (Parus palustris). J. Anim. Ecol. 58: 619-636.

Nimer, E. (1979) Climatologia no Brasil. Série Recursos Naturais e Meio Ambiente no 4. Rio de Janeiro: Instituto Brasileiro de Geografia e Estatística (IBGE), Superintendência de Recurso Naturais e Meio Ambiente (SUPREN).

Paiva, L. V. (2008) Fatores que determinam o período reprodutivo de Elaenia chiriquensis (Aves: Tyrannidae) no cerrado do Brasil Central. Brasília: Tese de Doutorado, Universidade de Brasília.

Priddel, D., Carlile, N. and Wheeler, R. (2006) Establishment of new breeding colony of Gould's petrel (Pterodroma leucoptera leucoptera) through the creation of artificial nesting habitat and the translocation of nestlings. Biol. Conserv. 128: 553-563. 
Ribeiro, J. F., and Walter, B. M. T. (1998) Fitofisionomias do bioma Cerrado. Pp. 89-166 in S. M. Sano and S. P. Almeida, eds. Cerrado: Ambiente e flora. Planaltina, Distrito Federal: EMBRAPA.

Ricklefs, R. E. and Bloom, G. (1977) Components of avian breeding productivity. Auk 94: 86-96.

Robinson, W. D., Robinson, T. R., Robinson, S. K. and Brawn, J. D. (2000) Nesting success of understory forest birds in central Panama. J. Avian Biol. 31: 151-164.

Silva, M. C. Jr. and Felfili, J. M. (1996) $A$ vegetação da Estação Ecológica de Águas Emendadas. Brasília: SEMATEC, IEMA.

Skutch, A. F. (1949) Do tropical birds rear as many birds as they can nourish? Ibis 91: 430-455.

Skutch, A. F. (1966) A breeding bird census and nesting success in central America. Ibis 108: 1-16.

Snelling, J. C. (1972) Artificial incubation of sparrow hawk eggs. J. Wildl. Manage. 36: 1299-1304.

Sousa, N. O. M. (2008) Teste de fatores que afetam o tamanho da ninhada de Elaenia chiriquensis (Tyrannidae) no cerrado do
Brasil central. Brasília: Dissertação de Mestrado, Universidade de Brasília.

Spear, K. A., Schweitzer, S. H., Goodloe, R. and Harris, D. C. (2007) Effects of management strategies on the reproductive success of Least Terns on dredge spoil in Georgia. Southeast. Nat. 6: 27-34.

Stutchbury, B. J. M. and Morton, E. S. (2001) Behavioral ecology of tropical birds. San Diego, California: Academic Press.

Tullet, S. G. (1990) Science and the art of incubation. Poult. Sci. 69: 1-15.

Verboven, N., Ens, B. J. and Dechesne, S. (2001) Effect of investigator disturbance on nest attendance and egg predation in Eurasian Oystercatchers. Auk 118: 503-508.

Visschedijk, A. H. J. (1991) Physics and physiology of incubation. Brit. Poult. Sci. 32: 3-20.

White, G. C. and Burnham, K. P. (1999) Program MARK: survival estimation from populations of marked animals. Bird Study

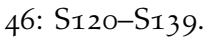

Wilson, K. A., McBride, M. F., Bode, M. and Possingham, H. P. (2006) Prioritizing global conservation efforts. Nature 440: 337-340.

\section{YONARA LOBO}

Programa de Pós-graduação em Ecologia, Instituto de Ciências Biológicas, Universidade de Brasília, Brasília, 70910-90o, DF, Brazil.

\section{MIGUEL ÂNGELO MARINI*}

Departamento de Zoologia, Instituto de Ciências Biológicas, Universidade de Brasília, Brasília, 70910-900, DF, Brazil.

*Author for correspondence; e-mail: marini@unb.br

Received 8 February 2011; revision accepted 2 November 2011; Published online 3 April 2012 